\title{
Germination Potential of Aspergillus niger and Fusarium solani Spores on Live Gyrinops walla Stem Tissues
}

\author{
Dias A.A.P. ${ }^{*}$, Fernando K.M.E.P. ${ }^{2}$ and Subasinghe S.M.C.U.P. ${ }^{1}$ \\ ${ }^{I}$ Department of Forestry and Environmental Science, University of Sri Jayewardenepura, Sri Lanka \\ ${ }^{2}$ Department of Botany, University of Sri Jayewardenepura, Sri Lanka \\ *piyali.d90@gmail.com
}

\begin{abstract}
Gyrinops walla (Walla patta) is the only member of the family Thymelaeaceae naturally growing in Sri Lanka which produces agarwood, a fragrant resinous tissue which is highly demanded in the world market. Since natural formation is rare, fungal inoculations are commonly practiced to induce agarwood formation in Aquilaria species. However, the response of live wood tissues of $G$. walla for the growth of fungi has not been investigated, the present study was conducted to identify the behavior of the fungal spores on the G. walla stem tissues after the inoculation. Non-resinous, non-wounded, fresh G. walla stem samples were collected minimising contaminations and water loss from three different mature trees with the age of 10-15 years in three different locations. Samples were cut into $3.0 \times 3.0 \times 3.0 \mathrm{~cm}$ and cutting surfaces were sterilised and $5 \mathrm{ml}$ of spore suspension of $10^{7}$ spores $\mathrm{ml}^{-1}$ and $10^{5}$ spores $\mathrm{ml}^{-1}$ of Aspergillus niger and Fusarium solani respectively were applied to four vertical surfaces of the wood cube until those were saturated and placed in a sterile moist chamber. Three replicates were used for each tree for both fungal species and spore germination in sterile distilled water was used as the control. Percentage of spore germination on live tissues was determined at every 3 hour intervals for 36 hours and data were analysed by Kruskal-Wallis test using MINITAB software. Results revealed that the percentage of germination was higher in $F$. solani spores than A. niger after 3 hours of incubation on fresh $G$. walla tissues. Further at the $15^{\text {th }}$ hour, germination was almost equal in both $A$. niger and $F$. solani. Though $A$. niger germination was lower until the $15^{\text {th }}$ hour, it was gradually increased with time and obtained the maximum germination percentage at about nearly $70 \%$ at the stationary phase. However, $F$. solani germination was lower after the $15^{\text {th }}$ hour and reached its maximum level of about $66 \%$. However, the germination of $A$. niger and $F$. solani spores on live $G$. walla wood were not significantly different $(\mathrm{p}=0.817)$. The findings of the present study showed that percentage of spore germination of $A$. niger on live wood (70\%) was higher than in water (60\%). Similarly $F$. solani also showed an increment of germination on live wood $(66 \%)$ than in water $(53 \%)$. Results revealed that the germination on live wood tissues of A. niger and F. solani was not inhibited by biochemical/ phytochemical compounds in wood of $G$. walla on the cutting surface. The findings demonstrated the compatible interactions between two tested fungal species and $G$. walla stem tissues.
\end{abstract}

Keywords: Germination, Gyrinops walla, Aspergillus niger, Fusarium solani, Wood tissues

Proceedings of the International Forestry and Environment Symposium 2016, Department of Forestry and Environmental Science, University of Sri Jayewardenepura, Sri Lanka. 